DOI: https://doi.org/10.46630/phm.12.2020.34

Јелена 3. Милић ${ }^{1}$

Универзитет у Нишу

Филозофски факултет

Департман за српску и компаративну књижевност
Оригинални научни рад УДК 821.163.41.09-32 Матавуљ С.

Примљен: 24. 12. 2020.

\title{
ЈАВНИ И ПРИВАТНИ ЖИВОТ У МАТАВУЉЕВИМ БЕОГРАДСКИМ ПРИЧАМА
}

\begin{abstract}
Полазећи од схватања литературе као секундарног моделативног система, у складу са методолошким поставкама Јурија Лотмана као представника семиотичке тартуско-московске школе, овај рад за предмет истраживања има слику приватног и јавног живота у Матавуљевим београдским причама. С обзиром на то да у теорији J. М. Лотмана уметнички простор представља важно конструктивно начело којим се изражавају и други, непросторни односи, у раду се анализирају међусобне релације и преплитања различитих видова приватног и јавног живота са индивидуалним/колективним, физичким/менталним спацијалним сферама у културном контексту Београда с краја деветнаестог и почетка двадесетог века.

Кључне речи: јавни и приватни живот, простор, контекст, Београд, Матавуљ
\end{abstract}

\section{1. Приватан живот и простори приватности}

Током Матавуљевог првог доласка у Београд 1887. године бива изневерена пишчева жеља да настави живот и рад у овом граду. Уместо тога, добио је службу у Зајечару где је два месеца остао да ради као учитељ. Након две године, септембра 1889. године, Симо Матавуљ поново долази у Београд и остаје у њему до изненадне смрти 1908. године. Последњих двадесет година свог живота Матавуљ је провео у српској престоници, што му је дало довољно времена да, према пишчевим речима, упије град свим чулима и осети како „мирише, види (се) и чује” (MATAVULJ 2009: 247-248). Према тачном запажању Горана Максимовића, Симо Матавуљ је поседовао „снажну способност опсервације нових простора и брзог усвајања нових језичких обиљежја" (MAKSIMOVIĆ 2004: 138), због чега уметничка имагинација и интерпретација реалности у његовим приповеткама дају уверљиву и уметнички вредну слику јавног и приватног живота Београђана.

11jelenamilic018@gmail.com 
Предмет истраживања овог рада јесу Матавуљеве београдске приче чија се радња одвија у културном контексту Београда с краја деветнаестог и почетка двадесетог века. Анализом наведеног пишчевог опуса, указаћемо на различите категорије приватног и јавног, као и на утицај друштвених конвенција на колективне и индивидуалне просторе приватности. Теоријско-методолошку основу рада чини семиотичка теорија уметничког простора Јурија Лотмана, са посебним освртом на сагледавање литературе као секундарног моделативног система и уметничког простора као конструктивног начела којим се изражавају непросторни односи. Као ефикасно интерпретативно полазиште за ово истраживање показала се и појмовна дистинкција „приватног простора” и „места приватности" историчара уметности Мирослава Тимотијевића. Семиотички и наратолошки утемељеним књижевнонаучним приступом Матавуљевим београдским причама, тежимо да дамо допринос како проучавању ауторске поетике овог приповедача, тако и расветљавању ширег културног контекста у којем су приче о поменутом поднебљу обликоване. У складу са тим, наше истраживање се, такође, придружује актуелним интердисциплинарним проучавањима историјских феномена дугог трајаға (тзв. „историји приватног живота”).

Конкретни животни и економски услови у београдским причама одређују свакодневицу становништва, а јавност дефинише посебан модел приватности грађанског друштва. У свакодневици Матавуљевих јунака откривамо њихове менталне географије приватности које су психолошки и емоционално изнијансиране. Као простори у којима појединац треба да буде у зони комфора, према дефиницији историчара уметности Мирослава Тимотијевића, приватни простори су:

„ментална колико и физичка категорија, која се доживљава различито, у зависности од културног оквира, начина урбанизације, типа заједнице у којој се живи, структуре односа на којој се она заснива, али и од сваког појединца понаособ. Исти физички приватни простор чланови једне заједнице користе различито, па га самим тим и доживљавају на различит начин" (TIMOTIJEVIĆ 2006: 165).

Матавуљев поступак организовања просторних релација у причама о животу Београђана, кореспондира са Лотмановим сагледавањем просторних структура као моћних организационих центара текста око којих се формира сложена семантика:

„будући да представља принцип организације и распореда ликова у уметничком континууму, структура топоса се појављује као језик који служи за изражавање других, непросторних односа у тексту. С тим је у вези основна моделативна улога уметничког простора у тексту" (LOTMAN 1976: $302)$. 
У београдским причама долази до прожимања колективног, индивидуалног, приватног и јавног времена и простора. Партикуларизацијом простора успоставаљају се и различите опозиције: општи и заједнички, колективни и индивидуални, отворен и затворен, свет који припада дану и свет који припада ноћи, тајни и јавни свет. „Менталну географију приватног простора” (TIMOTIJEVIĆ 2006: 165) у српској престоници деветнаестог и почетком двадесетог века, усложњава егзистирање српског становништва на географском простору Хабзбуршке и Аустроугарске монархије, Османског царства, Кнежевине, а потом и Краљевине Србије. Услед бурних друштвеноисторијских дешавања и коегзистенције различитих националних, социјалних, културних и верских модела, успостављају се различити концепти приватности.

У Матавуљевим причама о животу Београђана породични дом се јавља као један од најчешћих простора приватности. У односу према простору куће грађанина деветнаестог века, дом треба да представља „центар његовог света”, место где се могу „заборавити или вештачки одстранити проблеми и противречности грађанског друштва”, простор у коме је породица могла да „потхрањује илузију хармоничне хијерархизоване среће, окружена материјалним предметима који су ту срећу видљиво изражавали и истовремено је омогућавали" (SIMIĆ 2006: 145). Свакодневицу унутар простора дома сачињавају домаћи ритуали који симболично указују на сигурност унутар породичног круга и хладноћу спољног света. Слике свакодневице у конкретним хронотопима развијене су приказивањем материјалне културе Београђана и дошљака, детаљним описима ентеријера, изгледа, моде и јеловника српског грађанина на прелазу из деветнаестог у двадесети век, до помињања лектире која се читала у одређеним круговима. Културолошка асимилација дошљака често је приказана преко описа материјалне културе, преображаја простора дома и одеће јунака, какав је случај са одломком из приповетке $\mathrm{Ho}$ воверичи:

„У малој радионици смести се лепа гвоздена пећ... Па онда донеше Тимини људи једну полицу и две јаке столице. Па се онда појави велика 'гасна“ лампа са зеленим штитом. Перса се 'понови“ - замени нажуте хаљине тамнијим, које и боље доликоваху њеном испосничком лицу” (MATAVULJ 2007: 17).

Како су места приватности „места у простору, јавном и приватном, на којима појединац и група могу да остваре појединачну и колективну приватност” (TIMOTIJEVIĆ 2006: 167), можемо говорити о колективним и индивидуалним приватним просторима. Становници прича из београдског живота утврђују властита места приватности у различитим просторима (сокацима, квартовима, центру града, чаршији, породичном дому, 
спаваћој соби, дворишту итд.). Кварт и породични дом представљени су као зоне сигурности у којој живе најближи рођаци, суседи и пријатељи, али и као места угрожене приватности. Познато лице у простору породичног дома може да узурпира његову приватност, какав је случај са кумом из приповетке На юен дан и Аранђелом у причи Аранђелов удес. Пуштање црквеног лица у простор куће резултат је поверења према намерама представника хришћанских врлина. У приповеци Нововерци институције контроле су избрисале границу између приватног и јавног домена, па црквено лице злоупотребљава свој положај нарушавајући приватност породице назарена. Матавуљ ликове назарена ставља у положај потлаченог над којим се насиље врши у име закона општеприхваћеног концепта побожности. Лик свештеника репрезентује официјалну истину, црквену догму и њен утицај на приватност грађана. Узурпиран простор приватности постаје огледало јавног мњења које Мити додељује годину и по дана тамнице јер је спречавао свештеника у вршењу дужности.

У приповеци Мала жртва, човек који прима непознатог госта у приватни простор дома, долази у опасност да буде преварен у њему. У истој приповеци уочавамо сучељавање два типа приватности (личне и брачне) који паралелно егзистирају унутар простора породичног дома. Радознала жена упорно жели да зађе у просторе личне приватности свог супруга не би ли сазнала неки детаљ из његовог љубавног живота. Супруг јој, напослетку, приноси ту „малу жртву”, нов податак у „познавању његове душе" (MATAVULJ 2007: 111). Његову заинтересованост за необичан призор неба након олује, олако ће прекинути песма пијанице. Запитан пред необично брзим буђењем човекове радозналости за животе људи којима је окружен, овај Матавуљев јунак закључује:

„Да ми је знати која ли је оно пијаница што се онако дере и, по свој прилици, посрће? Радо бих дознао: ко је он? Чим живи? Којих је година? Кога има? Зашто се опија? Изгледа да су та питања недостојна пажње пред оваквим величанством природног призора, али ипак човека највише занима човек!"” (MATAVULJ 2007: 111).

Свакодневни живот и поступке јунака Матавуљевих београдских прича одређује људска радозналост и интересовање за туђу приватност. Чекајући свог познаника, радознали наратор приче Филаделфија се пре одлучује да изађе на терасу и посматра свакодневицу Филаделфије, него да чита новине. Муртал (Мурталов случај) слуша кораке и гласове са тротоара испод прозора, замишља обличја пролазника и нагађа њихове мисли. Наратор приче Предмет за причу из радозналости ступа у приватан простор дома пензионисаног начелника Коче Илића и постаје сведок необичног односа домаћина и његовог слуге: „Закопка ме да разберем шта ли је пензионеру толико до тога да 'уђе у књигу' неки' чудни и 
страшни догађај“" (MATAVULJ 2007: 372).

У приповеци Нововеричи фокус приповедача упућује на важност јавног мњења већ на почетку приповетке. Публика ће пропратити сваки тренутак Јожине посете мајстору Мити: „беше се скупила пред вратима и пред прозором гомила гледалаца. Макарена стајаше раменом до прага, како могаше гледати и мајстора и пијаницу, а да они њу не виде” (MATAVULJ 2007: 15). Након основних информација о пресељењу обућара и његове жене, истакнут је прецизан опис њиховог најближег комшилука у новој, београдској средини.

„Реч ’нововерци' полети најпре из Макарениних уста, па сврну кроза све куће у тој улици. Матори је готово шапатом изговараху, те се деца плашаху њеног нејасног значења, замишљајући да је налик на 'караконџулу“" (MATAVULJ 2007: 13).

„И тако нововерцима испираху уста, премда њих двоје мало с ким речи проговорише.” (2007: 15)

Заинтересованост за туђу приватност у приповеци Дигов посао дата је у форми унутрашњег монолога и тока свести јунака приповедача. Недоумице и истинска интересовања поводом Диговог понашања и посла остају неизречена у дијалогу, па се Дигов саговорник знатижељно пита шта је Диго изоставио причајући свој живот, зашто је променио име и ко је његов тајанствени непријатељ:

„Ма, ако је Ставра глуп, ниси ти, па зашто се не прионеш око заједничког посла? И како то да, како ми се чини, Крста не верма много ни тебе ни Ставру, а ни ви господари један другога?” (MATAVULJ 2007: 81)

Одмах након читања вести о убиству такозваног М. К., радознали Дигов земљак одлази у болницу и распитује се код болничара о његовом изгледу. Када одговор на питање не пронађе ни у кафани, наредних неколико недеља помно прати вести по београдским новинама, не би ли себи разјаснио недоумицу око Дигове умешаности у убиство, а земљакова знатижеља не јењава ни до тренутка јунакове садашњости: „Кад се сетим догађаја, питам се: да ли и то не беше Дигов посао?” (MATAVULJ 2007: 91)

\section{2. Структура и употреба приватног простора}

У Матавуљевим причама из београдског живота нема искључиве приватности и изолованости. Наратор приче На прагу другог живота директно позива наратера да уђе у туђ простор: „Иако је данас велика жега, иако је сад у невреме (Петров дан године $189 *$ око два часа после 
подне) ипак уђимо у кућицу" (MATAVULJ 2007: 120). Приватан живот се не одвија у четири зида, те је простор куће приказан као „симбол заједничког, социјализованог, неотуђеног простора", а не као интимни простор (VUKIĆEVIĆ 2006: 477).

Смағивање и партикуларизација простора од општег као појединачном треба да воде ка његовој приватизацији, док у општем приказу простора дома, кућни прозор и праг треба да представљају границе које одвајају приватно од јавног. У сликању приватног живота Матавуљ, међутим, увек оставља место за доконог, радозналог шетача, случајног посматрача, судију, уходу, процењивача, треће око које завирује и прислушкује. Чак и најинтимније мисли и најдубља приватност јунака београдских прича дате су из перспективе сведока, а не учесника.

У оваквом концепту приватности као једно од важнијих питања јавља се позиција посматрача. Њиховим дијалозима и поступцима најчешће управљају кодекси заједнице, те се иза изреченог крије вредносна перспектива средине:

„Доминација људи над човеком из дијахронијске перспективе делује као утопизам реалистичких писца који још увек верују у неуништивост одређених категорија (...) Иако припадају фикцији, а не документима, реалистички текстови нуде обиље података о тој још увек нераскидивој, унутар себе добро избалансираној сфери приватно-јавног живота Срба у другој половини 19. века" (VUKIĆEVIĆ 2006: 482).

У приповеци Аранђелов удес преко дискурса комшија, као представника јавног мњења, добијамо информације о Аранђеловим врлинама и његовој стидљивости. Слуга Ужичанин у причи Нововерци, исцрпно препричава како је у cmony пратио нове суседе: „Он их је пратио до Лондона, где се они разделише. Неки ће право, неки ће Кнез Милошевом улицом, па около, неки ће преко Западног Врачара" (MATAVULJ 2007: 13). Становници Филаделфије прекидају свој посао не би ли чули расправу у суседном врту: „Цинцарин се исправи и напери уши, његово слушче на прагу наклони се и разјапи уста, берберин прекиде тамбурање, и сви под багренима извратише главе” (2007: 208). Читава прича У Филаделфији изграђена је заправо на перспективи суседа и њиховим информацијама о приватном животу шароликог људског света необичног београдског сиротињског кварта.

Матавуљеве београдске приче указују на важност осећаја приватности у појединим деловима јавног простора. Степен приватности неког места одређује се према томе колико се „појединац или група у њему осећају као код куће" (TIMOTIJEVIĆ 2006: 167), сигурно и заштићено. У приповеци Последюе наздравље пензионисани чиновник Алекса Б. који је преласком из провинције у Београд остварио свој и женин сан, 
најпријатније се осећа „у својој улици, у својој кафани”, где има „своје одређено место” (MATAVULJ 2007: 276). У београдским кафанама „нема неовлашћеног приступа кафанском столу, а и када се то дозволи приступ не пролази без извесног противљења" (РЕЈС̆IĆ 2011: 88). Тројица пријатеља из приче Кандидат постају узнемирена када им Ферт саопшти да ће сместити и четвртог госта за њихов сто. За свој сто су, наглашава приповедач, ретко примали још неког, и то само уколико је добар познаник бар једног од њих. У београдским кафанама с краја деветнаестог и почетка двадесетог века постојале су и засебне просторије за забрањене радње које су биле намењене затвореном кругу људи. Типску слику једне такве кафане Матавуљ даје у приповеци Дигов посао, уметнички обликујући свет тајне београдске коцкарнице.

Различити разлози за окупљањем у градској средини (у кругу породице, родбине, пријатеља, комшија итд.) условљени су личним и колективним потребама или обавезама становника престонице. Јунаци београдских прича стављају колективне маске и удружују се у родне, верске, класне, социјалне, узрасне и етничке групе. При томе, идеолошка позиција групе омогућава покретање или непокретање различитих интимних тема међу њеним члановима. Јунакиња приче Београдска деца издваја теме које се покрећу међу припадницима истог друштвеног сталежа, ословљавајући их на следећи начин: „отприлике као и ми, ја ти, тетка, браца итд., наш круг” (MATAVULJ 2007: 426). У сценама приватне побожности назарена у приповеци Нововерци, издавајају се теме које се могу покренути међу припадницима исте верске културе, а у истој причи уочавају и теме које се покрећу искључиво међу припадницима истог пола: „Извините (...) међу нама женама се може говорити: да нисте запатили болест после порођаја?” (2007: 18).

Преко теме скривене приватности у приповеци Дигов посао, Матавуљ уметнички обликује сложени лик јунака са митоманским и пикарским цртама, профил радозналог Диговог земљака и групни лик коцкара. У овој причи приватно остаје неизречено избегавањем одговора на питања саговорника „Ко-ји је то кру-пни човек?” (MATAVULJ 2007: 82), мењањем предмета приче, употребом елипсе или фигуре ретиценције „(нешто хтеде да рече па изостави)” (2007: 81).

Ступање у интимни простор стринине спаваће собе у приповеци Аранђелов удес антиципира инцестуозни чин. Газдаричина дозвола за улазак у њену спаваћу собу у причи Грешно дете пут је за придобијање детета и упознавање са још интимнијим сегментом живота, неверством са кумом. Интимна размишљања јунака Матавуљевих београдских прича доступна су и непознатим силама. У причи Чудни разговори дух вишег реда чује интимне мисли лика-приповедача и ступа у простор његовог 
стана. У приповеци Спиритисте, сан као феномен који се везује за простор најдубље интиме, ступивши у јавност бива протумачен у зависности од убеђења својих тумача.

Иза колективних маски јунака Матавуљевих прича из београдског живота скривено је најинтимније и подсвесно, а интима ликова је преведена на „дозвољен метафоричан говор” (VUKIĆEVIĆ 2006: 478). У функцији скривања интимног као вида наративне цензуре, наћи ће се следећи уметнички поступци: замена првог лица једнине првим лицем множине, рестриктивност у саопштавању, приказивање интимних тренутака из перспективе других (сведока или свезнајућег приповедача), превођење емоција у формуле ,дрхће им глас, нешто стеже у грлу, дође им нешто тешко, у грудима бесни бура, у глави се роје силне мисли” (2006: 478).

Исповест и приватно писмо као облици приватног извештаја и самооткривања, присутни су у приповеци Београдска деца. Алузије су чести пребацивачи у поље цензурисаног приватног. Посредством алузије развијају се скривене приче у машти читаоца, какав је случај са постепеним увођењем мотива прељубе у приповеци На юен дан (преко портретисања детета и приказивања односа између жене и кућног пријатеља). Завршетке са примесама алузије налазимо у приповеткама Дигов посао (где је читаоцу остављено да одлучи да ли је Диго заиста постао убица) и Аранђелов удес (у којој читалац може само да претпостави да је дете настало из инцестуозног чина Аранђела и стрине, а ту је и дилема да ли јунак живот окончава смрћу утапањем у реци након инцестуозног чина или наставља животни пут очишћен од греха).

Један од примера убацивања додатне фокализаторске инстанце налазимо у опису побожне интиме назарена у приповеци Нововерции. У цитираном одломку фокализатор је мајстор Тима који се примиче Митином прозору не би ли сазнао разлог Јожине посете Мити:

„Она имаше у руци неку књижицу зелених корица. Кад седе између њих, Шандор скиде шубару и баци је на подину. Она поче читати гласно. (...) Мита слушаше с великом пажњом, али по Шандорову изразу лица могло се судити да не разуме... Једаред обућар окрете главу ка жени и диже прст, а на то се њене обрве јаче узвише, очи боље засјаше, те упре прстом у неку реч и застаде. Па онда опет настави читање" (MATAVULJ 2007: 27).

У причи Фронташ двориште је истовремено јавни простор (доступан оку средине), и приватни (простор за испољавање нереалних жеља). Док Драгишин стари познаник изненађено посматра чету малих војника u ґиховог официра, виртуелни јунаков излет за одрасле суседе представља обичну свакодневицу која није вредна пажње. Баба и девојка које седе на степеништу не обраћају пажњу на сцену у дворишту (баба плете, 
а девојка туца кафу), док су деца из суседства једина публика која верно прати кретање војске. Након завршене вежбе са малим војницима, баба изнесе из куће столицу, Драгиша седне и упали цигарету, док девојка наставља да туца кафу.

Степен приватности неког простора одређује се и у зависности од његове величине, намене и организације. Становници сиромашних квартова принуђени су и навикнути да деле тренутке приватности са својим суседима, док се у богатије уређеним просторима до туђих тренутака приватности долази отежаним путем. Организација простора у насељу названом Филаделфија је таква да је суседима увек доступна туђа приватност. У дну дворишта начичкани су „квартири” са „по једном собом и кујном”, у којима се ,збијају сиротињске главе” (MATAVULJ 2007: 210). И сав тај свет ,улази кроз једну капију, служи се једном чесмом и једном помијаром, и вазда су у заједници...” (2007: 210).

\section{3. Простори јавности}

Јавна сфера на ширем плану треба да обухвата државне институције и друштвене установе. Јавност, међутим, егзистира у различитим сферама јавних и приватних простора: ,државе, друштва, верске организације, нације, градске и сеоске заједнице, економско-материјалног друштвеног слоја" (MAKULJEVIĆ 2006: 17), због чега долази до мешања категорија приватног и јавног. Услед мешања ових категорија приватни живот почиње да се „остварује према жељеним или наметнутим културним концепцијама, политичким оквирима и економским условима" (2006: 17).

Култура смрти у српској грађанској култури деветнаестог и првим деценијама двадесетог века може се сагледати као „феномен састављен од посебности појединца у оквирима државне контроле” (BOROZAN 2006: 907). Концепт умирања припадника грађанске класе подразумавео је учешће јавности, наступање главних актера погребне представе (ожалошћених и уважених посетилаца), и одржавање сећања на преминулог. Првобитна функција помена и посмртних читуља у новинама, као главном генератору јавног мњења, била је упознавање јавности са организовањем помена. Обичај да се поменима обележава породични годишњи циклус, указује на грађанску свест о важности личног и заједничког времена проведеног у кругу породице.

У великом броју Матавуљевих приповедака о животу Београђана јавља се мотив смрти, који је представљен као део људске свакодневице. У Матавуљевим београдским причама наглашени су аспекти живота који претходе смрти или они који се настављају након ње (живот после смр- 
ти и живот живих). Основна тема приповетке Сукоби јесте непрекидна смена смрти и обновљеног живота. Смрт нема епитет ужасног, а смех и љубав који се настављају постоје попут ње, као чињенице живота.

Жеља за афирмацијом у градској средини повезана је и са борбом против анонимности. Наступање на јавном простору и потреба за привлачењем пажње јавности као теме се јављају у бројним Матавуљевим причама о београдском животу. Протагониста приче Шематизам добија напад панике када схвати да се његово име није нашло у новом броју Шематизма. Веља брзо облачи капут и креће ка министарству непрекидно понављајући: „Ја сам мртав... Сахранише ме живог! Мене нема па нема!" (MATAVULJ 2007: 204-205). Бившем великосудији очигледно не пада тешко што је после два месеца пензионисан, већ што није оставио своје име у државном календару. У приповеци Нововерии професор богословије хода „укрућен (...) ловећи очима поздраве” (2007: 12). Г. Коча из приче Предмет за причу преувеличава значај сопствене приватности са циљем да наметне другима високо мишљење о себи. Јунаково нерадо повлачење са сцене јавног простора у анонимни простор приватности пропраћено је непомиреношћу са идентитетом заборављеног пензионисаног начелника.

\section{4. Живот Београђана између приватног и јавног}

Матавуљеве београдске приче пружају увид у животе припадника појединих професионалних категорија у српском друштву. Већина трговачких, занатлијских и чиновничких породица имала је слуге, најчешће ђаке дошљаке, који су у замену за смештај обављали кућне послове. Емотивни свет и свакодневица појединца са станивишта ђака који су одлазили на школовање у Београд, приказани су у приповеткама Грешно дете и Дете. Свакодневицу детета слуге чини сан у тврдој постељи, живот у мраку, хладноћа у међуљудским односима и испомоћ у газдинствима која му пружају оскудан смештај и нешто хране. Наведене околности су у тој мери уобичајена појава у животу сиромашних ђака послужитеља, да приповедач често користи елипсу приликом описивања њихове животне свакодневице: „За неколико дана не деси се ништа знатно у животу Алексе Павловића" (MATAVULJ 2007: 47). Велику радост Алекси причињава и ретко понуђена кафа у домаћинствима које опслужује, а камоли када добије прилику да посети позориште.

Једну трећину, или чак половину укупног броја становника Београда представљали су самци, што је значајно утицало на економски положај и оформљивање породичних заједница. У причи Влајкова тајна 
Матавуљ даје типску слику приватне собе која се изнајмљивала сиромашнијим самцима:

„сва дрвенарија беше просто трухла. Гвоздени креветац храмао је на једну ногу, углачани сто пукао по средини, а на тако танким ногама, да би од једног јачег ударца песницом отишао у комаде! Тако је било све остало покућство; орман, умиваоник, диван и три столице” (MATAVULJ 2007: 182).

Новац представља важан чинилац приватног и јавног живота Београђана. Жена је била симбол друштвеног статуса уколико је потицала из угледне и имућне породице, па је иза склапања бракова са богатим девојкама често стајала жеља младића за побољшањем материјалног и друштвеног статуса. Ћерке богатих трговаца имале су највеће миразе, због чега су биле најпожељније удаваче. Дошљак Муртал у приповеци Мурталов случај правећи животне прорачуне планира да се ожени имућном удавачом, али неочекивано завршава са ћерком газдарице стана који изнајмљује. Милорад и чиновникова ћерка у причи На прагу другог живота, играју „комедију велике заљубљености" (MATAVULJ 2007: 122) у којој девојка све време остаје резервисана према младићевом удварању надајући се бољој прилици. Наглашавајући класну неједнакост момка и девојке, приповедач са призвуком ироније нуди читаоцу неопходно објашњење за шетњу чиновникове ћерке са ,послужитељским сином, скорашњим судопером” (2007: 122): „али потребно је било да се то зна, да се може објаснити, а, ако устреба, и оправдати што се она последње године његова школовања шета са њим” (2007: 122). Да јавни простори могу бити места тајности и скривања сведочи наредни одломак, у коме се наглашава да заљубљени пар пажљиво бира доба дана за своје сусрете, избегавајући притом прометна места: „Додуше то никад није бивало на Калемегдану, нити иначе пред очима њених родитеља, него онако случајно, на улици...” (2007: 122).

На простору који одређује културни плурализам истовремено егзистирају различити концепти приватности условљени културним моделима заједнице којој појединац припада. Свакодневна збивања попут дружења, посета, оговарања, неверстава и бесциљних завођења, утичу на друштвену структуру Београда. „Женска поткултура” (VULETIĆ 2006: 125) флерта, завођења, преотимања партнера, жеље за допадањем и промискуитетно понашање, значајно је усмеравала ток друштвених збивања. Сликајући поједине јунакиње београдских прича (мадам Младеновић у причи Гледајући Хамлета, неверну жену у приповеци Мала жртва, куму из приче $У$ Филаделфији) Матавуљ указује на двоструке аршине прихватљивости промискуитетног понашања у градској средини, где је слободније понашање удате жене више толерисано.

Политику рода у српској престоници последњеих деценија деветнаестог века креирао је њен мултикултурални идентитет. У Хабзбуршкој 
монархији жена дела у јавном простору још од осамнаестог века, док је у Османском царству била везана за простор породичног дома. Друштвене улоге жена и мушкараца почињу да се модификују и прилагођавају новим временима. Жене у урбаним срединама почињу чешће да се жале на своје мужеве него жене на селу, имајући притом ,широк распон очекивања од својих мужева" (VULETIĆ 2006: 126). На појаву масовног образовања жена из богатих породица Матавуљ често указује ироничним коментарисањем помодних навика Београђанки које се односе на учење популарних страних језика и хобија: „што је главно - зна прилично француски, разуме немачки, прилично добро дрндара по клавиру, по Калемегдану се креће слободно...” (MATAVULJ 2007: 121).

Јунаци Матавуљевих београдских прича егзистирају у нестабилном друштвеном контексту, као носиоци унутрашњих сукоба које узрокује неусаглашеност приватног и јавног домена. У приповеткама Аранђелов удес, Београдска деца и На юен дан, Матавуљев београдски свет руши норме које владају у односима међу супружницима и рођацима. Упркос привидним напорима ликова да ступе у туђе интимне садржаје, одсуство емпатије и наглашена отуђеност због немогућности разумевања другог, узрокују поремећаје у различитим видовима међуљудских односа. Хладноћа снега и погледа пролазника у Алексином сну (Грешно дете) представљају рефлектовану слику јаве и велеградске реалности која лик детета суочава са нехуманошћу одраслих људи. Контрастирани пејзажи реалног и оностраног света у Маријном сну (Марија), бездан, мрачна празнина, црна вода, призори уских, тамних улица и бескрајна, дивна цветна пољана на крају сна, сликовито описују раскорак између мрачног београдског света који јунакиња напушта, и идиличног, непознатог у који одлази након смрти.

„Рубна позиција ће се”, према тачном запажању Драгане Вукићевић, „препознати и у самом центру, као црв који разара језгро, у декаденцији и самоурушавању београдске елите" (VUKIĆEVIĆ 2014: 230). У Матавуљевој слици београдске елите уочава се поступак ,изокренуте хијерархије" при чему је хијерархијско горе често морално доле (BAHTIN 1978: 420). Типска слика становника центра српске престонице дата је у приповеци Београдска деца:

„Но треба да знаш да су мушкарци страшни коцкари, а према осталом апсолутно немарни. Женске су површне, превртљиве, кокетне, потрошљиве и тако даље. Могу бити лепе, просто залуђивати својом лепотом и грацијом. Ти си данас дивно београдско дете” (MATAVULJ 2007: 430).

Свакодневицу београдских станодаваца чине свађе због алкохола и коцке, преваре, промискуитетно понашање газдарица (Грешно дете), монотона свакодневица, доколица, брак без деце и лоши односи међу 
супружницима (Београдска деца, На њен дан). Портретисањем станодаваца у причи Грешно дете приказана је шароликост београдског света. Ту је стари нежењени судија тврдица код кога се Алекса смрзава и који, напослетку, умире од упале плућа, предузимач благе нарави и његова хистерична жена, брачни пар глумаца пргаве нарави, добродушна пензионерка, ћутљиви професор и причљива жена. Један од највећих хришћанских празника јунак приче Чудни разговори проводи сам, без најближих, заборављајући на Бадње вече. Наумов син (Наумова слутња) Београђанин се разводио два пута, одан је пићу и у лошим је односима са оцем. У приповеци На њен дан, на дан рођења своје жене, муж обелодањује дугогодишњу женину прељубу пред гостима, дарујући јој прстен. У приповеци На забави четворица младића у фраковима посматрају разноврсни свет који долази на јавно предавање, дајући типску слику јавног простора Београда:

„А свет је једнако навирао - шарени београдски свет, који ти већ својом спољашношћу напомиње да се налазиш у месту где се судара Исток са Западом, где се навикама и обичајима нагло прелази из једне крајности у другу. Међу старијим госпођама преовлађује такозвана 'српска ношња' - на главама тешки бисерни тепелуци, или лаки црвени фесићи, па онда либаде свију боја, а од појаса сукња по европској ношњи. (...) Па онда се нижу млађе и зреле девојке у француској ношњи, већином лепа обличја, која изражавају умност и слободу духа. (...) Па онда пролазе коштуњави и космати људи, снажних вилица, прави сељачки типови, који као да се осећају спутани у црним узаним хаљинама. Па онда трговци са добро обријаном брадом. (...) Па онда младићи, или истински елегантни или са претензијама на елеганцију, а готово сви нејачи, телесно неразвијенији од старијег нараштаја" (MATAVULJ 2007: 137-138).

Матавуљева прича На забави сликовито предочава тему наступања на јавном простору и колективни лик публике. Седам женских пратиља господина Квокића мењају све могуће позе, не би ли их публика осмотрила са сваке стране. Госпођица Лепосава Стошићева, једна од најбогатијих београдских удавача, мирно посматра очекиване погледе публике: „Под унакрсном ватром стотине погледа ниједна јој се црта не помери, него с осмејком одговараше малим поклоном десно и лево" (MATAVULJ 2007: 139). Наглашавајући важност јавног мњења и његову неизбежну умешаност у приватност Београђана, приповедач коментарише како је Лепосава „била на гласу као образована и духовита“ као и да „није никаква тајна била да је њу Павишић просио” али да је „највише изгледа било да ће поћи за Батрића”. Зато публика „са радозналошћу гледаше обојицу кад уђоше за њом” (2007: 139; подв. J. М.).

Различити видови приватности испољавају се у простору који се сматра јавним, на забавама, свечаним манифестацијама и културним до- 
гађајима. Нараторка приче Београдска деца указује на нове друштвене обавезе становника градске средине: „Та има ли шта досадније и бедније од наших журова, прстенова, свадби и осталих скупова како год их звали? (...) већ знам да ћу се готово са свима морати здравити, љубити, упознавати, говорити...” (MATAVULJ 2007: 428). Након сажетог описа сусрета у запрежним колима и наговештаја инцестуозног чина, јунакиња своја осећања транспонује на опис амбијента Београда: „Боже, диван ли је Београд! Чисте ли су улице, лепе и складне зграде, свет питом и укусно одевен!" (MATAVULJ 2007: 432). У причи На забави тематизован је помодни обичај Београђана да посећују културне догађаје само како би били сматрани делом градске, културне елите и примећени на месту академских окупљања.

„Бити на неком месту, одлазити на одређену врсту забава (...) значило је припадати тој друштвеној групи. Ти нови обрасци понашања постали су знак препознавања. Они су једној групи давали печат оног што је заједничко, а самим тим и оног што ту групу одваја од других, хијерархијски нижих слојева" (STOJANOVIĆ 2009: 340).

Наслов На забави писцу је послужио као паратекстуални, иронични коментар о академској свести београдске културне елите којој је значајно предавање о историји позоришта представљало само вид забаве. Предавање као важан културни догађај остаје у позадини приче, док се као њен главни предмет јављају лицемерје, похлепа, корупција и сплеткарења групе посетилаца који се налазе испред сале.

У приповеци Гледајући Хамлета пажњу публике и јунака приповедача не привлачи извођење Шекспирове драме, већ јавно појављивање фаталне Јуноне. Паралелним низањем сегмената који описују сценски наступ гостујуће трупе и Јунонино наступање у публици, представљена је лична, интимна драма коју јунак доживљава посматрајући мадам Младеновић. Иако приповедачев исказ повремено има подругљив, иронијски тон, делотворност пејоративних исказа намењених посланиковој жени поништава говорникова засењеност њеном појавом. Успех мадам Младеновић се не темељи на таленту, нити на њеној необичној природи и похотној лепоти, већ, пре свега, на способности да наступа на јавном простору и постане предмет опште пажње. Фатална Јунона зна да ће удајом за посланика бити у жижи јавних дешавања, као и да ће изненадна вест о њеној смрти и оповргавање информације повећати интересовање знатижељне публике.

Јавни простор може послужити и као погодно место за решавање приватних несугласица. Чланови Женског добротворног друштва (Седница женског добротворног друштва) током седнице износе у јавност приватне, интимне проблеме. Добротворна акција као повод окупљања 
постаје споредна ствар, јер се разговор окупљених претвара у међусобно препирање чланова удружења и борбу око расподеле моћи у њему. Ова Матавуљева прича се завршава тако што се седница разиђе, а да притом нико и не сазна шта је било на дневном реду.

Разрађена метафорика кретања има велики значај у Матавуљевој уметничкој слици града. Као важни чиниоци карактеризације јунака београдских прича, релације у простору су представљене различитим метафоричким варијацијама хронотопа пута (кретање јунака, животни пут, пут душе и др.). Прагови на које јунаци наилазе прелазећи реалне путеве, представљају границу и страх да се она прекорачи, животни преокрет, „место кризе, падова, ускрснућа, обнова просветљења, одлука које одређују читав живот човека" (BAHTIN 1989: 378). У сценама шетњи дати су панорамски описи града и уведене епизоде са неочекиваним сусретима и догађајима који одређују даљи ток кретања простором (какав је случај са неочекиваним исходом шетње наратора приче Цигански укоп). Мотив сусрета присутан је као важан сегмент свакодневице, приватног и јавног живота Београђана. Бројни организовани и случајни сусрети указују на особиту динамичност која прати живот српске престонице, као и на хаотичност у разним сферама друштвене и приватне свакодневице ликова. Сусрет на улици одређује судбине јунака, изазива мешање светова, сталежа, животних искустава. Композициона функција овог мотива остварена је његовим различитим варијацијама и везом са другим мотивима (брак, бекство, препознавање, разилажење, контакт, сусрет и конфликт различитих идеолошких позиција итд.). Након једног непланираног сусрета у приповеци Христос Воскресе!, на отвореном јавном простору (пред заводом за умоболне) престаје заштитно дејство родитељског дома, и размажена девојчица бива поучена „грозном појавом живота" (MATAVULJ 2007: 352).

У складу са социјалним контекстом, јунаци Матавуљевих београдских прича непрекидно идентификују и диференцирају себе и другог, при чему свесно или несвесно активирају једну од варијанти вишеструког идентитета. ${ }^{2}$ Природа испољених идентитета на јавним и приватним просторима зависи од одређеног типа односа који јунаци желе да успоставе према себи, простору, времену, другој особи или са актерима одређене друштвене групе. У изненадној трагедији и самоћи, главна јунакиња приче Cпиритисте улаже велике напоре да потисне своје интимне жеље, мисли и осећаје, усредређујући се на очекивања јавног мњења и различите наметнуте представе о томе како треба да изгледа као удови-

\footnotetext{
2 Детаљном анализом вишеструких идентитета јунака Матавуљевих београдских прича као последицама сукоба између приватног и јавног домена, бавимо се у раду Идентитет и контекст: уметничка слика града и људи у Матавуљевим београдским причама (в. MILIĆ 2020).
} 
ца. Тежећи ка јединственом идентитету и оствареној егзистенцији, Фема се труди да усагласи своје интимне жеље са очекивањима јавности, што потврђују њени покушаји да улогу жене адекватно замени друштвеном улогом удовице, а лик паорке прекрије маском учене жене. Још један од Феминих спутаваних идентитета, настао као последица сукоба између слободне и угрожене приватности, активира се у простору њеног породичног дома, непосредно након губитка мужа. Свезнајући приповедач наглашава да јунакиња након мужевљеве смрти више није била везана никаквим распоредом и некадашњим кућним забранама, због чега је могла слободно да креира дан према личним потребама, „не бојећи се замерака Јевремових" (MATAVULJ 2007: 52). Ова Матавуљева јунакиња испољава социјалну надмоћ у односу са својим слушкињама, док током јавних наступа пред људима из вишег друштвеног слоја показује несигурност и подређеност. Из наведених разлога се и њени ставови према сујеверју мењају у зависности од јавног контекста у ком се изричу.

Поред уметничке интерпретације усменог преношења информација у виду трачева, Матавуљ у више наврата наглашава и значајну улогу штампе у креирању јавног идентитета становника Београда с краја деветнаестог и почетка двадесетог века. Фемина јака жеља да види своје име у новинама бива на ироничан начин остварена након објављивања посмртне читуље: „када замишља како се појављује пред хиљадама очију „те јој се чини да чује уздахе и шапат” (MATAVULJ 2007: 52). Јунакиња наступа пред јавношћу на сахрани и током четрдесетодневног помена свом супругу када плачући, једним оком посматра публику. Ликови у Матавуљевим београдским причама и најинтимније радње обављају са свешћу о непрекидном надзору средине, често изневеравајући сопствене жеље. Ни Фемина самостална шетња градом не пролази без свести о присуству трећег ока. Јунакиња љубазно поздравља пролазнике, па чак и оне којима се до тада није јављала јер јој „се чињаше да неко невидно прати не само њена дела него и њене мисли, те је желела да угоди томе невидљивом надзорнику" (MATAVULJ 2007: 69). Упркос унутрашњој потреби за зближавањем са новим суседима, јунакиња приповетке Нововеричи пажљиво испољава наклоност према ликовима назарена у јавности. Не заборављајући експлицитни суд јавног мњења о досељеницима назаренима, Макарена им опрезно упућује знаке поздрава, и то само уколико се нађе сама на вратима. Пред другима је редовно „пљувала за Персом и грдила 'нову веру'" (2007: 18).

У приповеци Cпиритисте унутрашњи сукоби у главној јунакињи, изазвани хаотичним преплитањима приватног и јавног домена, бивају разрешени под утицајем непознатих сила. Као њихов представник у поменутој Матавуљевој причи јавља се Фемин такозвани пророчански сан, 
који је један од одлучујућих фактора на коначан исход сукоба између приватног и јавног. Као људском искуству непознат простор, Фемин сан постаје погодно тло за најразличитија учитавања средине и њихових манипулација јунакињином свешћу и подсвешћу. Сан као феномен који се везује за простор најдубље интиме, симболично прелази границу приватног ступивши у јавност где бива различито протумачен у зависности од убеђења својих интерпретатора. Мистично дејство сна и његова пророчанска димензија остају у другом плану, док одлучујуће дејство на Фемину реалност имају интерпретације његових тумача. Оне симболизују разарајућу моћ средине, изазивају хаотичну смену и сукоб различитих идентитета у Феми, и узрокују трагичан, крајњи исход сиболичког преласка интимног у јавно.

Овим истраживањем тежили смо да сагледамо један модел приватности грађанског друштва који је уметнички интерпретиран у Матаљувљевим београдским причама. Анализом поменутог опуса показали смо да Матавуљеви простори јавног и приватног функционишу као показатељи непросторних релација у тексту - менталних образаца, културолошких асимилација, политике пола, културе смрти, црквених модела и обичаја. Рад, такође, указује на наративне стратегије којима су обликовани цензурисани садржаји у књижевности српског реализма, као и на могућности испољавања скривених интимних и приватних садржаја епистоларном формом, исповешћу или алузијама. Наша анализа уметничког простора у приповедној прози Симе Матавуља, утемељена је на два становишта која проблематизују тополошке функције приватног и јавног: 1. јавни простори могу бити препознати као простори тајанственог и скривеног; 2. простори дома и куће могу се тумачити као симболички простори отуђености и друштвеног ангажовања. Различити видови хронотопа пута и мотив сусрета представљају у Матавуљевој приповедној прози носиоце значајне семантичке информације, а њиховом интерпретацијом потврђује се да је у реалистичком тексту граница између приватног и јавног померива и флексибилна. Ка истом циљу била је усмерена и анализа ликова, претежно фокусирана на пажљиво уочавање психолошке мотивације јунака (скривених значења њихове брбљивости, радозналости, љубопитљивости, застрашености и сл.). При анализи сукоба између приватног и јавног домена, са циљем да одговоримо на питање (не)могућности усклађивања приватног и јавног деловања у свету приче, указали смо на проблеме који се због тих сукоба јављају, затим на жртве које јунаци приносе јавном животу и њихове напоре да простор интимног потисну, сакрију или очувају. 


\section{Цитирана литература}

BAHTIN 1978: BAHTIN, Mihail. Stvaralaštvo Fransoa Rablea i narodna kultura srednjeg veka i renesanse. Prev. Ivan Šop i Tihomir Vučković. Beograd: Nolit, 1978.

BAHTIN 1989: BAHTIN, Mihail. O romanu. Prev. Aleksandar Badnjarević. Beograd: Nolit, 1989.

BOROZAN 2006: BOROZAN, Igor. Kultura smrti u srpskoj građanskoj kulturi 19. i prvim decenijama 20. veka. Ana Stolić, Nenad Makuljević (prir.). Privatni život kod Srba u devetnaestom veku: od kraja osamnaestog veka do početka prvog svetskog rata. Beograd: Clio, 2006, 899-983. [orig.] БОРОЗАН, Игор. Култура смрти у српској грађанској култури 19. и првим деценијама 20. века. Ана Столић, Ненад Макуљевић (прир.). Приватни живот код Срба у деветнаестом веку: од краја осамнаестог века до почетка првог светског рата. Београд: Clio, 2006, 899-983.

VUKIĆEVIĆ 2006: VUKIĆEVIĆ, Dragana. Privatni život u ogledalu realističke književnosti. Ana Stolić, Nenad Makuljević (prir.). Privatni život kod Srba u devetnaestom veku: od kraja osamnaestog veka do početka prvog svetskog rata. Beograd: Clio, 2006, 457-482. [orig.] ВУКИЋЕВИЋ, Драгана. Приватни живот у огледалу реалистичке књижевности. Ана Столић, Ненад Макуљевић (прир.). Приватни живот код Срба у деветнаестом веку: од краја осамнаестог века до почетка првог светског рата. Београд: Clio, 2006, 457-482.

VUKIĆEVIĆ 2014: VUKIĆEVIĆ, Dragana. Urbane teme: šetnja Matavuljevim fikcijskim Beogradom. Dragana Vukićević, Snežena Milosavljević Milić. Ogledavanja: Laza Lazarević - Simo Matavulj. Niš: Filozofski fakultet 2014, 201-246. [orig.] ВУКИЋЕВИЋ, Драгана. Урбане теме: шетња Матавуљевим фикцијским Београдом. Драгана Вукићевић, Снежена Милосављевић Милић. Огледавања: Лаза Лазаревић - Симо Матавуљ. Ниш: Филозофски факултет 2014, 201-246.

VULETIĆ 2006: VULETIĆ, Aleksandra. Vlast muškaraca, pokornost žena između ideologije i prakse. Ana Stolić, Nenad Makuljević (prir.). Privatni život kod Srba u devetnaestom veku: od kraja osamnaestog veka do početka prvog svetskog rata. Beograd: Clio, 2006, 112-132. [orig.] ВУЛЕТИЋ, Александра. Власт мушкараца, покорност жена - између идеологије и праксе. Ана Столић, Ненад Макуљевић (прир.). Приватни живот код Срба у деветнаестом веку: од краја осамнаестог века до почетка првог светског рата. Београд: Clio, 2006, 112-132.

LOTMAN 1976: LOTMAN, Jurij Mihajlovič. Struktura umetničkog teksta. Prev. Novica Petković. Beograd: Nolit, 1976.

MAKSIMOVIĆ 2004: MAKSIMOVIĆ, Goran. Gradovi, podneblja i ljudi Sime Matavulja. Kazivanje grada i drugi ogledi. Niš: Filozofski fakultet, 2004. [orig.] МАКСИМОВИЋ, Горан. Градови, поднебља и људи Симе Ма- 
тавуља. Казивање града и други огледи. Ниш: Филозофски факултет, 2004

MAKULJEVIĆ 2006: MAKULJEVIĆ, Nenad. Pluralizam privatnosti: kulturni modeli i privatni život kod Srba u 19. veku. Ana Stolić, Nenad Makuljević (prir.). Privatni život kod Srba u devetnaestom veku: od kraja osamnaestog veka do početka prvog svetskog rata. Beograd: Clio, 2006, 17-53. [orig.] MAКУљЕВИЋ, Ненад. Плурализам приватности: културни модели и приватни живот код Срба у 19. веку. Ана Столић, Ненад Макуљевић (прир.). Приватни живот код Срба у деветнаестом веку: од краја осамнаестог века до почетка првог светског рата. Београд: Clio, 2006, 17-53.

MATAVULJ 2009: MATAVULJ, Simo. Građa. Sabrana dela Sime Matavulja. Knj. 8. Beograd: Zavod za udžbenike/ Zagreb: Srpsko kulturno društvo „Prosvjeta“, 2009. [orig.] МАТАВУљ, Симо. Грађа. Сабрана дела Симе Матавуља. Књ. 8. Београд: Завод за уџбенике/ Загреб: Српско културно друштво „Просвјета“, 2009.

MILIĆ 2020: MILIĆ, Jelena. Identitet i kontekst: umetnička slika grada i ljudi u Matavuljevim beogradskim pričama. [orig.] МИЛИЋ, Јелена. Идентитет и контекст: уметничка слика града и људи у Матавуљевим београдским причама. Jezik, književnost, kontekst: tematski zbornik radova. Vesna Lopičić, Biljana Mišić Ilić (ur.). Niš: Filozofski fakultet, 2020, 663-676.

PEJČIĆ 2011: PEJČIĆ, Aleksandar. Matavuljev(i) beogradski svet(ovi). Dragana Vukićević, Dušan Ivanić (ur.). Simo Matavulj: delo u vremenu. Zbornik radova sa Međunarodnog skupa Književno delo Sime Matavulja. Beograd: Filološki fakultet, 2011, 79-98. [orig.] ПЕЈЧИЋ, Александар. Матавуљев(и) београдски свет(ови). Драгана Вукићевић, Душан Иванић (ур.). Cимо Матавуљ: дело у времену. Зборник радова са Међународног скупа Књижевно дело Симе Матавуља. Београд: Филолошки факултет, 2011, 79-98.

SIMIĆ 2006: SIMIĆ, Vladimir. Svet deteta i njegova slika u srpskoj umetnosti 19. veka. Ana Stolić, Nenad Makuljević (prir.). Privatni život kod Srba u devetnaestom veku: od kraja osamnaestog veka do početka prvog svetskog rata. Beograd: Clio, 2006, 133-164. [orig.] СИМИЋ, Владимир. Свет детета и његова слика у српској уметности 19. века. Ана Столић, Ненад Макуљевић (прир.). Приватни живот код Срба у деветнаестом веку: од краја осамнаестог века до почетка првог светског рата. Београд: Clio, 2006, 133-164.

STOJANOVIĆ 2009: STOJANOVIĆ, Dubravka. Kaldrma i asfalt: urbanizacija $i$ evropeizacija Beograda 1890-1914. Beograd: Udruženje za društvenu istoriju, 2009. [orig.] СТОЈАНОВИЋ, Дубравка. Калдрма и асфалт: урбанизачија и европеизаиија Београда 1890-1914. Београд: Удружење за друштвену историју, 2009.

TIMOTIJEVIĆ 2006: TIMOTIJEVIĆ, Miroslav. Privatni prostori i mesta privatnosti. Ana Stolić, Nenad Makuljević (prir.). Privatni život kod Srba u devetnaestom veku: od kraja osamnaestog veka do početka prvog svetskog 
rata. Beograd: Clio, 2006, 165-244. [orig.] ТИМОТИЈЕВИЋ, Мирослав. Приватни простори и места приватности. Ана Столић, Ненад Макуљевић (прир.). Приватни живот код Срба у деветнаестом веку: од краја осамнаестог века до почетка првог светског рата. Београд: Clio, 2006, $165-244$.

\section{Извори}

MATAВУљ 2007: MATAVULJ, Simo. Pripovetke III. Sabrana dela Sime Matavulja. Knj. 3. Beograd: Zavod za udžbenike, 2007. [orig.] МАТАВУљ, Симо. Приповетке III. Сабрана дела Симе Матавуља. Књ. 3. Београд: Завод за уџбенике, 2007.

Jelena Milić

\section{THE PUBLIC AND PRIVATE LIFE IN MATAVULJ'S BELGRADE STORIES}

Starting from the Lotman's concept of literature as a secondary modelling system, this paper investigates the private and public life in the cultural context of Belgrade from the end of the nineteenth and early twentieth century in Matavulj's Belgrade stories.

Key words: public and private life, space, Belgrade, Matavulj 